\title{
Ailinella mirabilis gen. n., sp. n. (Eucestoda: Pseudophyllidea) from Galaxias maculatus (Pisces: Galaxiidae) in the Andean- Patagonian region of Argentina
}

\author{
Alicia A. Gil de Pertierra ${ }^{1}$ and Liliana G. Semenas ${ }^{2}$ \\ ${ }^{1}$ Laboratorio de Helmintología, Departamento de Biodiversidad y Biología Experimental, Facultad de Ciencias Exactas \\ y Naturales, Ciudad Universitaria, Pab. II, $4^{\circ}$ Piso, Universidad de Buenos Aires, C1428EHA-Buenos Aires, Argentina; \\ ${ }^{2}$ Laboratorio de Parasitología, Centro Regional Universitario Bariloche, Universidad Nacional del Comahue, Quintral 1250, \\ 8400-Bariloche, Provincia de Río Negro, Argentina
}
Key words: Pseudophyllidea, Triaenophoridae, Ailinella mirabilis, microtriches, tumuli, Galaxias maculatus, Patagonia

\begin{abstract}
Ailinella gen. n. (Pseudophyllidea: Triaenophoridae) is proposed to accommodate Ailinella mirabilis sp. n. from Galaxias maculatus (Jenyns, 1842), a freshwater fish inhabiting the Andean lakes in Argentinean Patagonia. Ailinella belongs to the Triaenophoridae because it has a marginal genital pore, a follicular vitelline gland, and a ventral uterine pore. The new genus can be distinguished from other triaenophorids by the following combination of characters: a small body size, a low number of proglottides, which are longer than wide, a truncated pyramidal to globular scolex, a rectangular apical disc, presence of the neck, lack of internal longitudinal musculature separating the cortex from the medulla, testes distributed in one central field surrounding the ovary laterally and posteriorly, the vagina predominantly anterior to the cirrus sac, vitelline follicles circum-medullary, the genital pores post-equatorial, a saccate uterus, and operculate eggs. Blade-like spiniform microtriches were present on all tegument surfaces, and tumuli on all surfaces of the scolex and the anterior surface of the neck. Microtriches were characterized according to their size and density, and tumuli according to their size, inter-tumulus distance and density. Ailinella mirabilis is the first cestode described from G. maculatus and the second triaenophorid species recorded from a South American freshwater fish.
\end{abstract}

Galaxiids are freshwater fishes that occur in cool temperate waters of the Southern Hemisphere including Australia, Lord Howe Island, Chatham Islands, New Zealand, Auckland and Campbell Islands (New Caledonia), southern South America, Malvinas Islands, and the southern tip of South Africa (Berra 2003). The family Galaxiidae comprises seven genera, but only the genera Aplochiton Jenyns, 1842 and Galaxias Cuvier, 1816 are represented in the Argentinean Patagonia (Berra 2003, Cussac et al. 2004). Three adult cestodes have been described in the area, of which two belong to the Proteocephalidea (Gil de Pertierra and Viozzi 1999, Gil de Pertierra 2002), and one to the Pseudophyllidea (Gil de Pertierra and Semenas 2005).

During an ichthyological survey of freshwater fishes in Patagonia, specimens of the osmeriform galaxiid fish Galaxias maculatus (Jenyns, 1842) harboured adult pseudophyllidean tapeworms in their intestines. These cestodes were assigned to the Triaenophoridae Lönnberg, 1889, but they could not be allocated to any of the recognized genera (Bray et al. 1994).

In this paper, a new genus is proposed within the Triaenophoridae to accommodate the species. In addition, the tegumental surface of the scolex, neck and proglottides were examined using scanning electron microscopy (SEM), and the results are compared with those from other pseudophyllidean species.

\section{MATERIALS AND METHODS}

A total of 761 specimens of the "puyen chico", Galaxias maculatus, were captured using baited traps in 28 lakes and lagoons from the Andean region of Argentinean Patagonia ( $39^{\circ} 09^{\prime} \mathrm{S}, 71^{\circ} 17^{\prime} \mathrm{W}$ to $50^{\circ} 25^{\prime} \mathrm{S}, 72^{\circ} 50^{\prime} \mathrm{W}$ ). Samples were taken only during the summers from 1995 to 2004 . Fish were captured from 0 to $50 \mathrm{~m}$ of depth in the lakes, and from 0 to $1.8 \mathrm{~m}$ of depth in the lagoons. All worms found in the intestines were removed and fixed in hot $4 \%$ formaldehyde solution and stored in $70 \%$ ethanol. Entire tapeworms were stained with Langeron's alcoholic chlorhydric carmine, differentiated in acid ethanol, dehydrated through a graded ethanol series, cleared in beechwood creosote, and mounted in Canada balsam. Details of internal anatomy were determined from serial cross-sections of proglottides embedded in paraffin, cut at 8 $\mu \mathrm{m}$ thick, stained with Harris' haematoxylin, and counterstained with eosin. Hand-cut cross-sections of proglottides stained with Langeron's alcoholic chlorhydric carmine were also examined. Spontaneously laid eggs were fixed in hot $4 \%$ formaldehyde solution, stored in $70 \%$ ethanol, and examined in distilled water. Four specimens were examined with a Philips XL 30 scanning electron microscope by the following procedure: specimens were post-fixed in $1 \%$ osmium tetroxide, dried with hexamethyldisilazane (Riedel-De $\mathrm{Haë}^{\circledR}$ ), mounted on stubs with adhesive tape, and sputter coated with gold in a Thermo VG Scientific Polaron SC 7630. The types and distribution of microtriches were studied on the scolex, 
neck, immature, mature and gravid proglottides of the specimens, as suggested by Thompson et al. (1980) and Richmond and Caira (1991). The microthrix terminology followed Hoberg et al. (1995). Microthrix density (MD) and tumulus density (TD) values were obtained by counting microtriches or tumuli from randomly selected areas of $1 \mu \mathrm{m}^{2}$ each. Intertumulus distance (IT) and diameter were also measured. Measurements of the microtriches and tumuli were taken from photomicrographs. Holotype and paratypes were deposited at the Parasitological Collection of the Museo Argentino de Ciencias Naturales "Bernardino Rivadavia", Buenos Aires, Argentina (MACN-Pa), a paratype and cross-sections at the Institute of Parasitology (IPCAS) AS CR, České Budějovice. Unless otherwise stated, all measurements are given in micrometres $(\mu \mathrm{m})$ as the range followed in parentheses by the mean, standard deviation and total number of observations (n). Illustrations were made with the aid of a camera lucida attached to a Zeiss Axioscope microscope. Fish samples were taken under the permission of the Argentinean National Parks Administration. Abbreviations used in plates: $\mathrm{CS}=$ cirrus sac, $\mathrm{EC}=$ excretory canal, $\mathrm{EG}=\mathrm{egg}, \mathrm{GP}=$ genital pore, $\mathrm{ISV}=$ internal seminal vesicle, $\mathrm{LM}=$ longitudinal musculature, $\mathrm{OP}=$ operculum, $\mathrm{OV}=$ ovary, $\mathrm{TC}=$ tegumental cytons, $\mathrm{TE}=$ testis, $\mathrm{UP}=$ uterine pore, $\mathrm{UT}=$ uterus, $\mathrm{VA}=$ vagina, $\mathrm{VC}=$ vaginal canal, $\mathrm{VD}=$ vitelline duct, $\mathrm{VF}=$ vitelline follicles, $\mathrm{VR}=$ vitelline receptacle.

\section{RESULTS}

\section{Ailinella gen. n.}

Diagnosis. Pseudophyllidea, Triaenophoridae. Small worms, strobila consisting of a low number of longer than wide proglottides. Scolex unarmed, truncated pyramidal to globular, with 2 shallow cup-shaped bothria. Apical disc rectangular with rounded corners in apical view, sometimes convex. Neck present. External and internal segmentation present. Secondary segmentation absent. Internal longitudinal musculature separating cortex from medulla absent. Single set of reproductive organs. Testes medullary, in one central field, and surrounding ovary laterally and posteriorly. Cirrus sac small and pyriform. Cirrus without visible microtriches or spines. Genital pores post-equatorial, lateral, irregularly alternating. Ovary posterior, symmetrically or asymmetrically bilobed. Vagina predominantly anterior to cirrus sac, without sphincter. Vitelline follicles occupy circum-medullary region of proglottides. Uterine pore midventral, uterus saccate. Eggs operculate, unembryonated. Parasites of freshwater teleosts. Type and the only species: Ailinella mirabilis sp. $\mathrm{n}$.

E t y m o 1 o g y : The genus Ailinella (a feminine) is dedicated to our daughters Ms Ailín Mazur and Ms Ailín Pertierra.

Remarks. Ailinella is placed in the Triaenophoridae Lönnberg, 1889, on the basis of the possession of a marginal genital pore, medullary testes, a posterior ovary, a follicular vitelline gland, and a ventral uterine pore situated medially.
The family currently includes 20 genera (Bray et al. 1994, Kuchta and Scholz 2004, 2006, Gil de Pertierra and Semenas 2005): Abothrium van Beneden, 1871; Amphicotyle Diesing, 1863; Amphigonophorus Mendes, 1944; Anchistrocephalus Monticelli, 1890; Anonchocephalus Lühe, 1902; Australicola Kuchta et Scholz, 2006; Bathybothrium Lühe, 1902; Bathycestus Kuchta et Scholz, 2004; Eubothrioides Yamaguti, 1952; Eubothrium Nybelin, 1922; Fissurobothrium Roitman, 1965; Fistulicola Lühe, 1899; Galaxitaenia Gil de Pertierra et Semenas, 2005; Marsipometra Cooper, 1917; Parabothrium Nybelin, 1922; Pistana Campbell et Gartner, 1982; Probothriocephalus Campbell, 1979; Pseudamphicotyla Yamaguti, 1959; Pseudeubothrioides Yamaguti, 1968; and Triaenophorus Rudolphi, 1793.

Ailinella is characterized by its small size; a low number of proglottides much longer than wide; testes distributed in one central field; internal longitudinal musculature separating cortex from medulla absent; vagina predominantly anterior to cirrus sac, and operculate eggs.

The new genus can be differentiated from Abothrium, Bathybothrium, Eubothrioides, Fissurobothrium, Parabothrium, Pistana and Probothriocephalus by possessing an apical disc (Bray et al. 1994).

Ailinella can be distinguished from the genera possessing apical disc as follows: Anchistrocephalus and Triaenophorus are characterized by having an apical disc with hooks (numerous hooks and trident-shaped hooks, respectively) and the absence of neck (Bray et al. 1994).

Amphicotyle possesses proglottides wider than long, bothria with a posterior region marked off like an accessory sucker (Yamaguti 1959, Bray et al. 1994 - fig. $10.65)$; testes in lateral fields or in one single field; cirrus armed; vitelline follicles in two laterodorsal and ventral fields, and the absence of neck (Bray et al. 1994 - fig. 10.65).

Amphigonophorus occasionally has scolex deformatus, deep bothria longer than wide (Bray et al. $1994-$ fig. 10.57), proglottides wider than long (Bray et al. 1994 - fig. 10.58), two sets of reproductive organs, and vitelline follicles in dorsal field only or surrounding the testicular region.

Anonchocephalus possesses a sagittate scolex with a casket-shaped apical disc (Suriano and Labriola 1998), proglottides wider than long, testes in two lateral fields connected posteriorly, vitelline follicles distributed ventral to testes, a coiled uterus and uterine pore situated anteromedially, and without neck.

Australicola can be discriminated by possessing a lanceolate scolex, a massive strobila with very short and wide craspedote proglottides, vitelline follicles distributed in a transverse equatorial band, and unoperculate eggs (Kuchta and Scholz 2006).

Bathycestus can be distinguished by possessing a sagittate scolex with two wide prominent bothria with 
slightly projecting posterior margins, a weakly developed apical disc, testes forming two separate longitudinal fields continuous in postovarian space, cirrus sac angled anteromedially, unoperculate eggs (Kuchta and Scholz 2004), and the absence of neck.

Eubothrium has a distinct or poorly developed apical disc; bothrial grooves conspicuous or inconspicuous, indentations present or absent (Andersen and Kennedy 1983, Hanzelová et al. 2002); neck present (Hanzelová et al. 2002) or absent; testes in two lateral fields that may be almost confluent; a median ovary; vitelline follicles usually in two fields not continuous longitudinally, situated cortical, or cortical to paramuscular, or paramuscular, or medullary to paramuscular (Nybelin 1922, Andersen and Kennedy 1983, Bray et al. 1994, Hanzelová et al. 2002); and unoperculate and embryonated eggs (Hanzelová et al. 2002).

Fistulicola has an arrow-shaped scolex, sometimes replaced by a pseudoscolex; a craspedote strobila with extended posterolateral margins; a strongly coiled uterus; and the absence of neck.

Galaxitaenia possesses wider than long to quadrangular proglottides; genital pores equatorial laterally; testes in two lateral fields, often connected anteriorly; a vagina posterior to cirrus sac; vitelline follicles medullary, in two ventral fields forming two wings interrupted medially; a saccate to branched uterus; and unoperculate eggs (Gil de Pertierra and Semenas 2005).

Marsipometra has oval bothria; first proglottides wider than long, mid-proglottides quadrangular, posterior proglottides slightly longer than wide; testes in two lateral fields connected anteriorly and posteriorly; ovary transversely reniform; vitelline follicles in two ventral fields or forming arches from ventral to dorsal sides (Yamaguti 1959, Bray et al. 1994).

Pseudamphicotyla can be distinguished by the presence of elongate bothria divided into several loculi; the absence of neck; a two-winged ovary, closer to genital pore than to aporal side; and unoperculate eggs (Yamaguti 1959, Bray et al. 1994 - fig. 10.67).

Finally, Pseudeubothrioides possesses an elongate scolex, bothria with smooth margins, proglottides wider than long except when fully gravid, testes in two lateral fields connected posteriorly to ovary, pre-equatorial genital pores, a vagina posterior to cirrus sac, and a strongly coiled uterus.

\section{Ailinella mirabilis sp. $\mathrm{n}$.}

Figs. 1-15

Description (based on 21 specimens: 10 complete and 7 incomplete specimens as whole mounts, 4 scolices observed with SEM, and pieces of strobila as cross-sections). Pseudophyllidea, Triaenophoridae. Small worms, up to $14-22 \mathrm{~mm}(18 \pm 3 ; \mathrm{n}=10)$ in total length; anapolytic, external and internal segmentation present, secondary segmentation absent (Fig. 1).

Scolex truncated, pyramidal to globular, equal or wider than neck, 230-660 (445 $\pm 149 ; n=10)$ wide in dorsoventral view (Figs. 4, 15A). Apical disc of scolex rectangular with rounded corners in apical view, sometimes convex (Fig. 1), 185-350 (268 $\pm 52 ; \mathrm{n}=10)$ long in dorsoventral view by $88(\mathrm{n}=1)$ wide in lateral view (Figs. 4, 6). Apical disc surface covered with small blade-like spiniform microtriches $0.50-0.56(0.52 ; \mathrm{n}=$ 6) long by $0.24-0.28(0.26 ; \mathrm{n}=6)$ wide at base. $\mathrm{MD}=$ $7-9(8 ; n=6)$ (Fig. 15B). Surfaces of apical disc, cavity and marginal ring of bothria, lateral scolex surface proximal to apical disc, and anterior surface of neck covered with tumuli. Tumuli on apical disc 1.56-2.01 $(1.80 ; \mathrm{n}=11)$ in diameter, $\mathrm{TD}=0.04-0.16(0.09 ; \mathrm{n}=$ $10)$, IT $=2.21-4.86(3.11 ; \mathrm{n}=9)$. Tumuli on lateral surface of scolex proximal to apical disc $1.40-2.40(1.90 ; n$ $=9)$ in diameter (Fig. 7), TD =0.04-0.16 $(0.10 ; n=10)$, IT $=2.22-5.74$ (4.00; $\mathrm{n}=10)$ (Fig. 7).

Two dorsoventral shallow cup-shaped bothria, 100$250(188 \pm 57 ; \mathrm{n}=11)$ long by $146-520(334 \pm 127 ; \mathrm{n}=$ 11) wide. Central cavity surface of bothria covered with slim blade-like spiniform microtriches 1.10-1.27 (1.20; $\mathrm{n}=5)$ long by $0.25-0.30(0.28 ; \mathrm{n}=5)$ wide at base. $\mathrm{DM}$ $=4-5(5 ; n=7)$ (Fig. 15C). Lateral surface of marginal ring of bothria covered with blade-like spiniform microtriches $0.79-0.97(0.91 ; \mathrm{n}=11)$ long by $0.37-0.50$ $(0.43 ; \mathrm{n}=11)$ wide at base. $\mathrm{MD}=4-5(4 ; \mathrm{n}=7)$ (Fig. 15D). Distal surface of marginal ring of bothria covered with blade-like spiniform microtriches 1.02-1.15 (1.08; $\mathrm{n}=7)$ long by $0.28-0.42(0.36 ; \mathrm{n}=7)$ wide at base. MD $=4-5(5 ; \mathrm{n}=7)$ (Fig. 15E). Non-adherent surface of bothria covered with blade-like spiniform microtriches $0.96-1.13(1.10 ; \mathrm{n}=6)$ long by $0.25-0.30(0.27 ; \mathrm{n}=6)$ wide at base. $M D=4-6(5 ; n=7)($ Fig. $15 F)$.

Neck $600-1,500(1,090 \pm 265 ; \mathrm{n}=10)$ long by 250 $670(401 \pm 148 ; n=10)$ wide; surface covered with blade-like spiniform microtriches $0.70-1.08(0.89 ; \mathrm{n}=$ 7) long by $0.18-0.26(0.21 ; \mathrm{n}=7)$ wide at base. $\mathrm{MD}=$ 6-7 (7; $\mathrm{n}=6)$ (Fig. 15G). Immature proglottides 4-9 (7 $\pm 2 ; \mathrm{n}=10)$ per worm, 220-2,000 (801 $\pm 520 ; \mathrm{n}=28)$ long by $220-640(372 \pm 111 ; \mathrm{n}=28)$ wide; surface covered with slim blade-like spiniform microtriches $0.91-$ $1.00(0.96 ; \mathrm{n}=7)$ long by $0.12-0.18(0.15 ; \mathrm{n}=7)$ wide at base. $\mathrm{MD}=7-10(9 ; \mathrm{n}=6)($ Fig. $15 \mathrm{H})$. Mature proglottides $1-3(1.3 \pm 0.48 ; \mathrm{n}=10)$ per worm, 1,200 $2,750(1,964 \pm 488 ; \mathrm{n}=10)$ long by $360-640(502 \pm 88$; $\mathrm{n}=10$ ) wide (Fig. 2); surface covered with slim bladelike spiniform microtriches $0.92-1.11(1.07 ; \mathrm{n}=6)$ long by $0.14-0.18(0.15 ; \mathrm{n}=6)$ wide at base. $\mathrm{MD}=6-8(7 ; \mathrm{n}$ 6) (Fig. 15I). Gravid proglottides $1-5(3.5 \pm 1.43 ; \mathrm{n}=$ 10) per worm, $1,480-4,640(2,603 \pm 645 ; n=29)$ long by $360-900(563 \pm 143 ; n=29)$ wide (Fig. 3$)$; surface covered with slim blade-like spiniform microtriches $0.55-0.68(0.60 ; n=6)$ long by $0.11-0.17(0.14 ; n=6)$ wide at base. $M D=7-15(11 ; n=6)$ (Fig. 15J).

The longitudinal musculature separating cortex from medulla is absent, but there are numerous slim longitudinal fibres among tegumentary cytons subadjacent to the tegumentary distal cytoplasm (Figs. 10-14). All genital organs and ducts are medullary. Longitudinal 


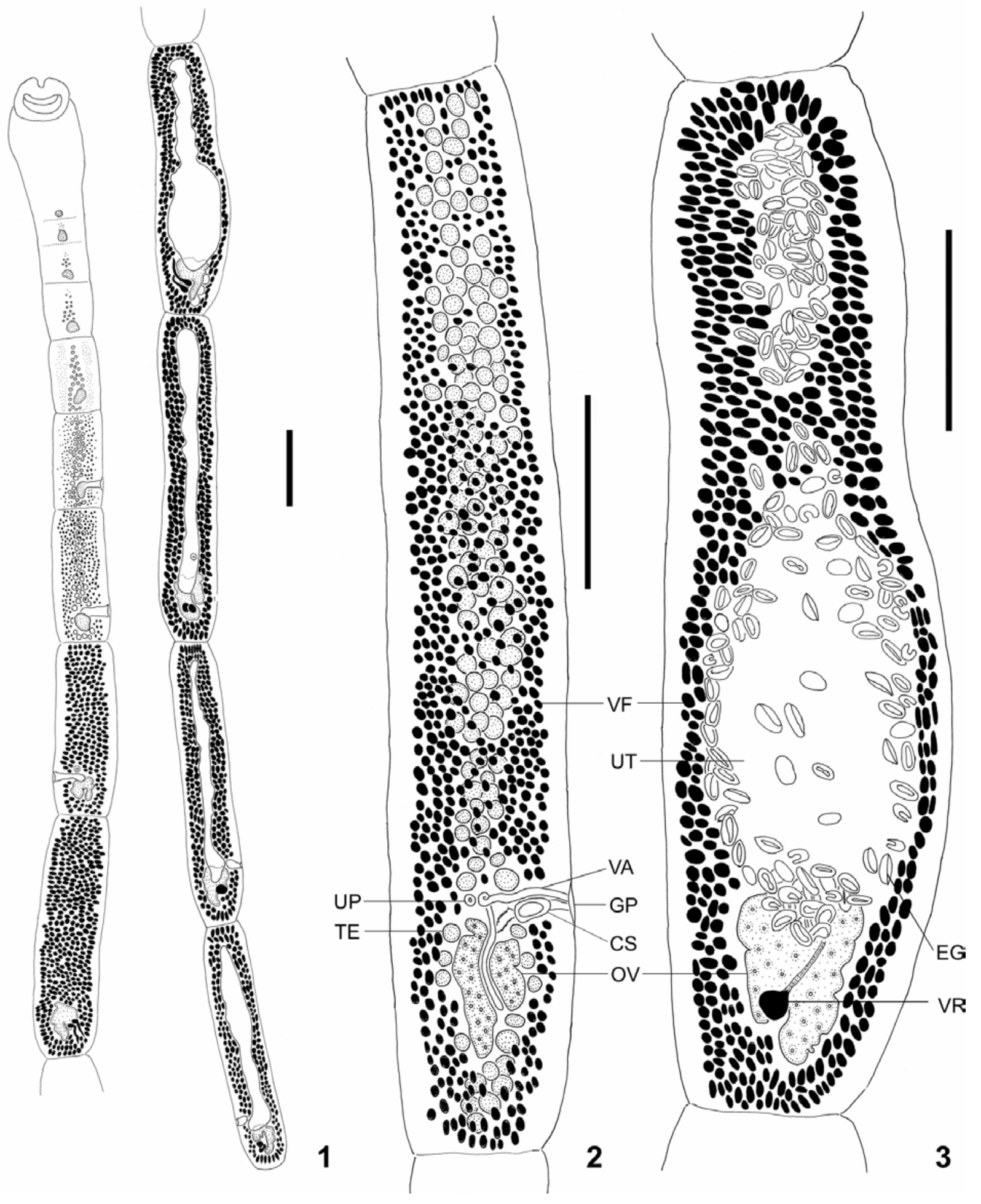

Figs. 1-3. Ailinella mirabilis gen. n., sp. n. Fig. 1. Entire worm showing scolex with contracted apical disc; ventral view. Fig. 2. Mature proglottid; vitelline follicles are partially represented in the anterior part of proglottid to show testes; ventral view. Fig. 3. Gravid proglottid; ventral view. Scale bars: Fig. $1=1 \mathrm{~mm}$; Figs. 2, $3=500 \mu \mathrm{m}$. 

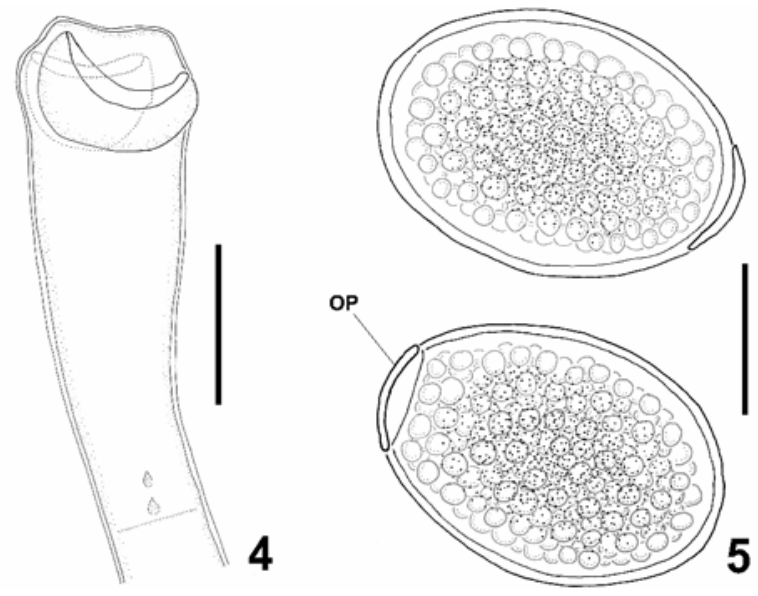

4

OP

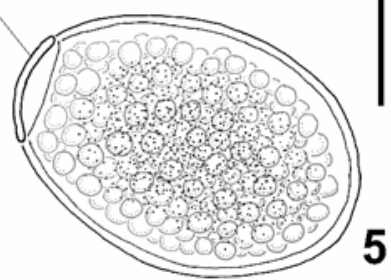

Figs. 4, 5. Ailinella mirabilis gen. n., sp. n. Fig. 4. Scolex; dorsoventral view. Fig. 5. Eggs after fixation, drawn in distilled water. Scale bars: Fig. $4=400 \mu \mathrm{m}$; Fig. $5=25 \mu \mathrm{m}$.
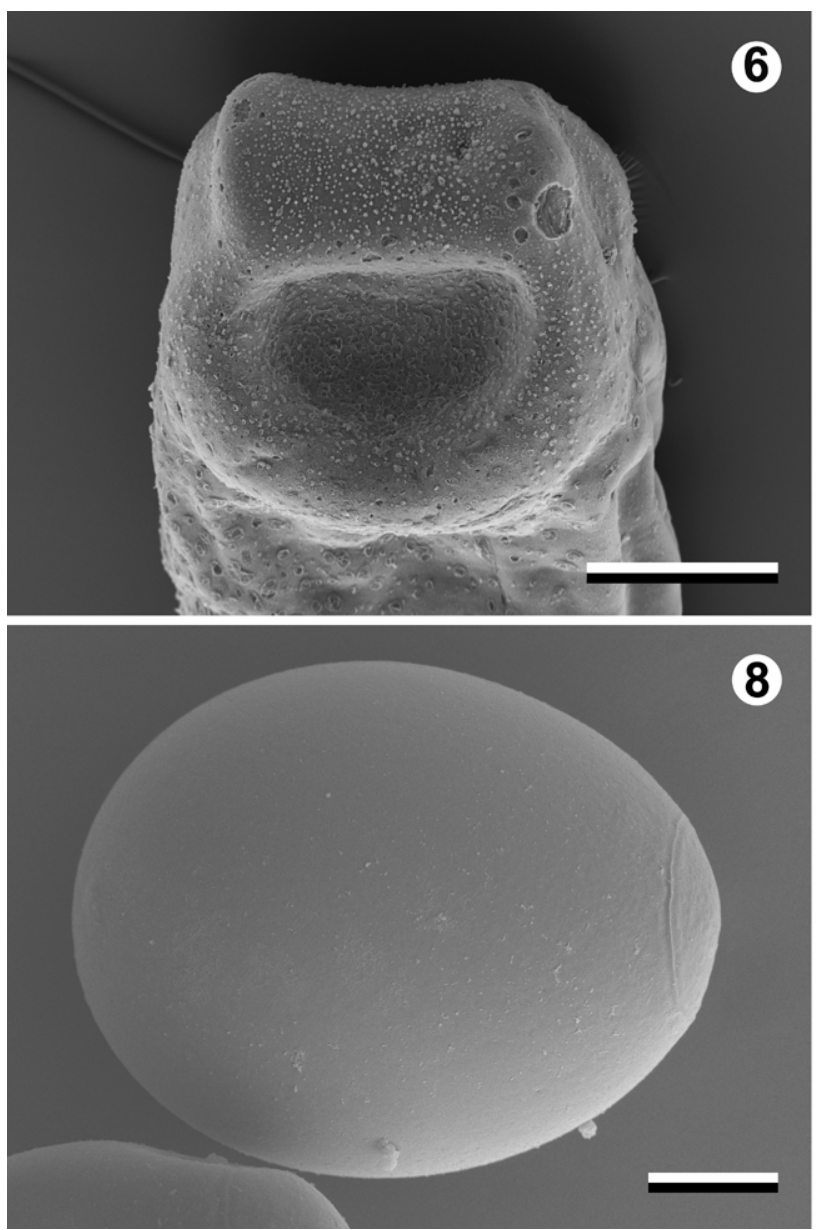

excretory canals in centrolateral medulla observed in cross-sections (Figs. 10-14), 5-8 on each side, 5-20 in diameter. Transverse anastomosis not observed.

Testes medullary in one central field along proglottid, interrupted dorsally and ventrally at ovary level, with few testes surrounding it laterally and posteriorly (Fig. 2). Testes spherical, 40-70 (61 $\pm 8.1 ; \mathrm{n}=13)$ in diameter, total number per mature proglottid 50-104 (70 $\pm 24 ; n=4$ ); degeneration of testes in gravid proglottides (Fig. 3). Cirrus sac lateral, globular to pyriform with thin muscular wall, 95-170 (131 $\pm 28 ; \mathrm{n}=10)$ long by $55-75(65 \pm 7 ; \mathrm{n}=10)$ wide when cirrus completely invaginated, occupying $17-33 \%(26 \pm 5 \% ; n=10)$ of mature proglottid width (Fig. 2). Internal seminal vesicle apparently present (Fig. 13). Cirrus without visible microtriches or spines. Vas deferens short and not coiled, 30 in diameter. Genital pores post-equatorial, lateral, irregularly alternating, situated 76-86\% (80 \pm $3 \% ; \mathrm{n}=10$ ) of proglottid length from anterior margin in mature proglottides (Fig. 2).
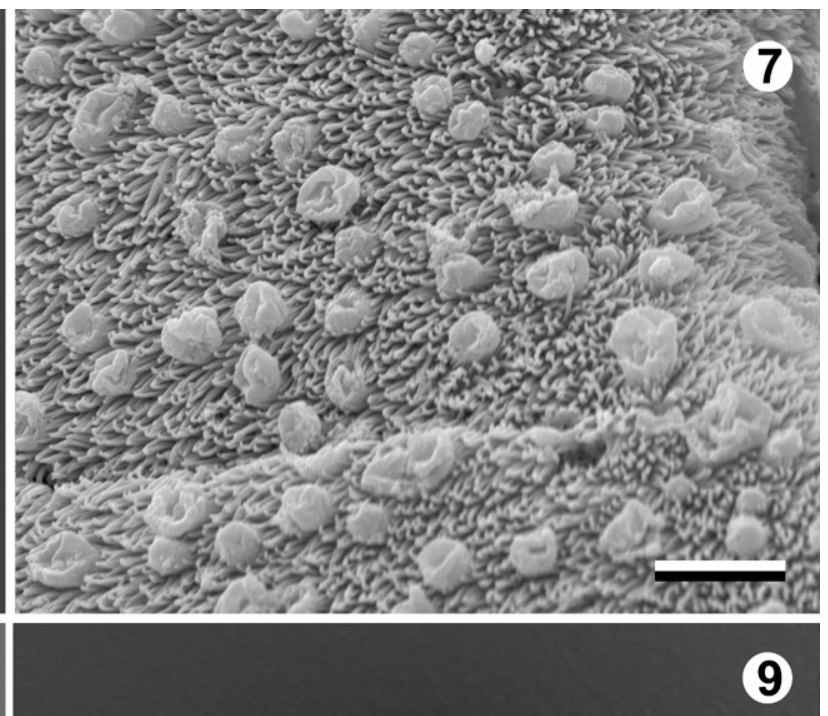

Figs. 6-9. Scanning electron micrographs of Ailinella mirabilis gen. n., sp. n. Fig. 6. Dorso-apical view of scolex showing relaxed apical disc. Fig. 7. Lateral surface of scolex showing tumuli. Fig. 8. Intrauterine egg, lateral view. Fig. 9. Apical view of intrauterine egg showing operculum. Scale bars: Fig. $6=100 \mu \mathrm{m}$; Fig. $7=5 \mu \mathrm{m}$; Figs. $8,9=10 \mu \mathrm{m}$. 

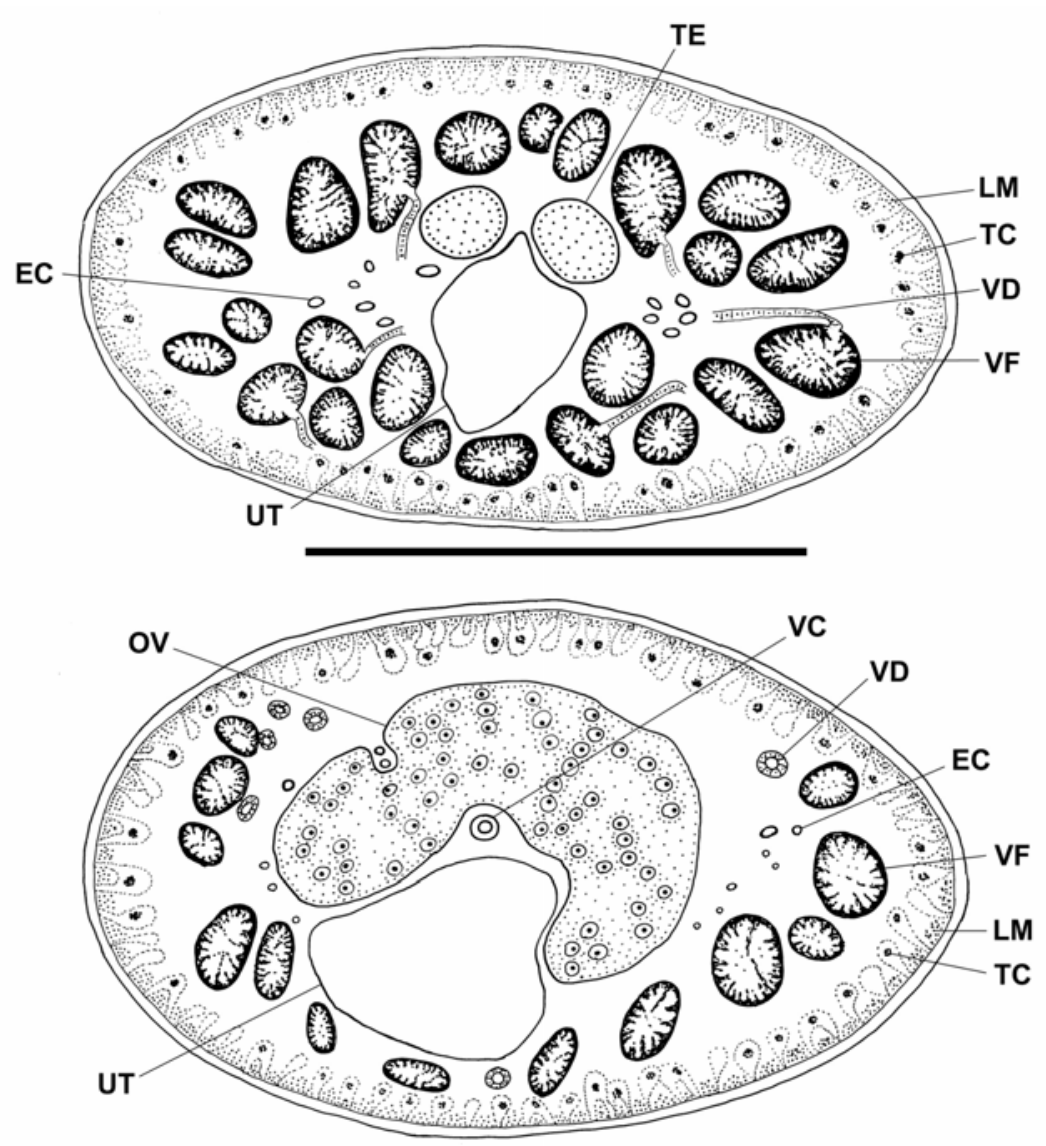

11

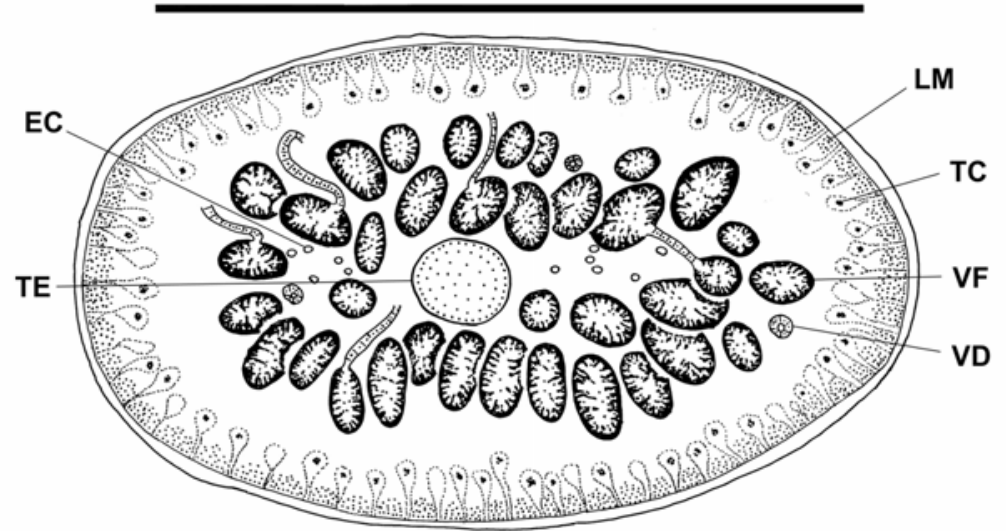

Figs. 10-12. Ailinella mirabilis gen. n., sp. n., mature proglottides. Fig. 10. Cross-section of middle of proglottid at the testes level. Fig. 11. Cross-section at the ovary level. Fig. 12. Cross-section posterior to the ovary. Scale bars: Figs. $10-12=300 \mu \mathrm{m}$.

Ovary posterior, usually bilobed or asymmetrically bilobed (with longer aporal lobe) in dorsoventral view in same specimen; $150-365(253 \pm 62 ; \mathrm{n}=10)$ long by 110-350 (204 \pm 64) wide; occupying 31-56\% (40 \pm $7 \% ; n=10)$ of mature proglottid width. Vagina parallels ventrally and slightly anterior (95\%) or slightly posterior $(5 \%)$ to cirrus sac, sphincter not observed (Figs. 2, 14). Vaginal canal up to $35-40$ in diameter, coiled as it descends to ovarian isthmus. Mehlis' gland not observed. Vitelline follicles in circum-medullary field
(Figs. 1, 2, 10, 12) interrupted dorsally at ovary level (Fig. 11); uninterrupted at level of testes (Figs. 10, 12), cirrus sac and vagina. In gravid proglottides uninterrupted dorsally (Figs. 13, 14), in older gravid proglottides ventral and dorsal follicles show lateral displacement (Fig. 3). Follicles large, oval to spherical, 50-75 long by $30-50$ wide in mature proglottides. Vitelline receptacles large, usually situated dorsally and ventrally, up to $80-85$ long by 60-75 wide (Fig. 3). 

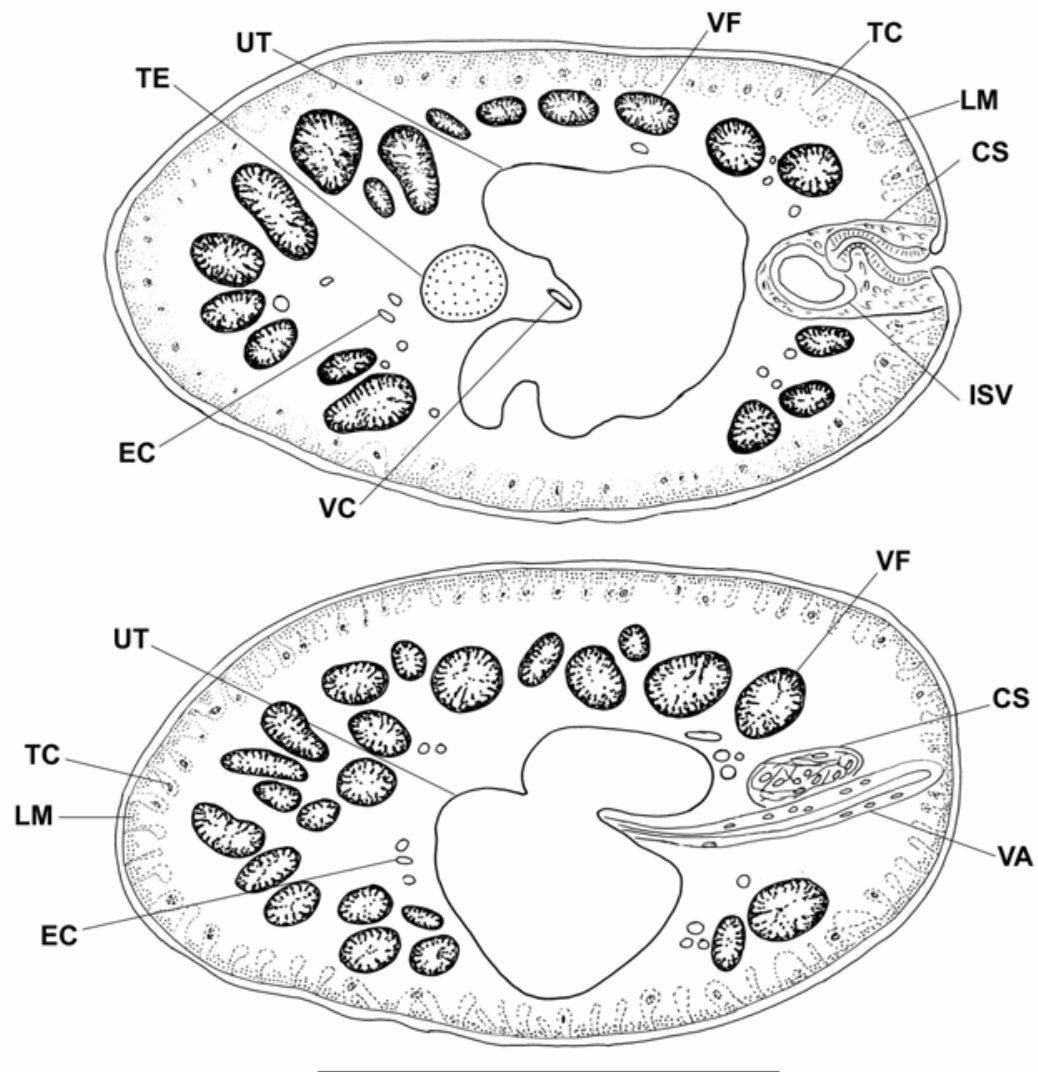

Figs. 13, 14. Ailinella mirabilis gen. n., sp. n., gravid proglottides. Fig. 13. Cross-section at the cirrus sac level. Fig. 14. Crosssection at the cirrus sac and vagina level. Scale bars: Figs. 13, $14=300 \mu \mathrm{m}$.

Uterine pore small, situated ventrally, musculature not observed (Fig. 2). Uterus saccate, visible only in gravid proglottides (Fig. 3) or in cross-sections of mature proglottides (Figs. 10, 11), not reaching anterior margin of proglottid and overlapping ovary anteriorly, occupies $26-86 \%(56 \pm 17 \% ; \mathrm{n}=25)$ of proglottid width. Eggs small, elliptical, 55-65 (60 $\pm 4 ; n=6)$ long by $35-49(43 \pm 6)$ wide, operculate and unembryonated. Operculum present in intrauterine eggs (Figs. 8, 9) and also in eggs spontaneously liberated from uterus (Fig. 5). Operculum 15-20 in diameter (Fig. 9).

Ty p e host: Galaxias maculatus (Jenyns, 1842) (Osmeriformes, Galaxioidea, Galaxiidae), vernacular name "puyen chico".

T y p e 1 o c a 1 i t y : Moreno Lake system (41 ${ }^{\circ} 03-04$ 'S, 71³0-31’W), Nahuel Huapi National Park, Río Negro Province, Argentina.

O the r lo c a liti e s: Neuquén Province (Lakes: Correntoso, Espejo, Espejo Chico, Falkner, Hermoso, Huechulaufquen, Lácar, Machónico, Meliquina, Nahuel Huapi, Norquinco, Traful, Tromen, and Villarino; lagoons: Bailey Willis, Patagua, and Piré); Río Negro Province (Lakes: Escondido, Guillelmo, Gutiérrez, Hess, Los Moscos, Mascardi, and Steffen; lagoons: Llum and Mallín Ingenieros); Santa Cruz Province (Lake Argentino).

Site of infection: Intestine.
P r e v a 1 e n c e : $24 \%$ in Moreno Lake system and $15 \%$ in the other localities.

Mean intensity of infection: 1.9 in Moreno Lake system and 1.8 in the other localities.

$\mathrm{S} p$ e c i m e n s d e p o s i t e d : Holotype MACN-Pa No. 434/1 (one whole worm); 5 paratypes MACN-Pa No. 434/2-6 from the type locality and from Gutiérrez Lake, Río Negro Province $\left(41^{\circ} 11^{\prime} \mathrm{S}, 71^{\circ} 25^{\prime} \mathrm{W}\right)$; cross-sections of proglottides MACN-Pa No. 434/7a-g; one paratype IPCAS C-438 from Tromen Lake, Neuquén Province $\left(39^{\circ} 32^{\prime} \mathrm{S}\right.$, $71^{\circ} 28^{\prime} \mathrm{W}$ ); and cross-sections of proglottides IPCAS C438.

E t y m o 1 o g y : From the Latin "mirabilis" meaning "marvellous", feminine in gender.

\section{DISCUSSION}

Ailinella mirabilis belongs to the Triaenophoridae as defined by Bray et al. (1994) because of the presence of marginal genital pores, medullary testes, an ovary situated posteriorly, follicular vitelline glands, and a ventral uterine pore. This species shows unique characters among the representatives of the family, such as a very small body size and a few number of proglottides, which are longer than wide and much longer than those of Pistana eurypharyngis Campbell et Gartner, 1982 

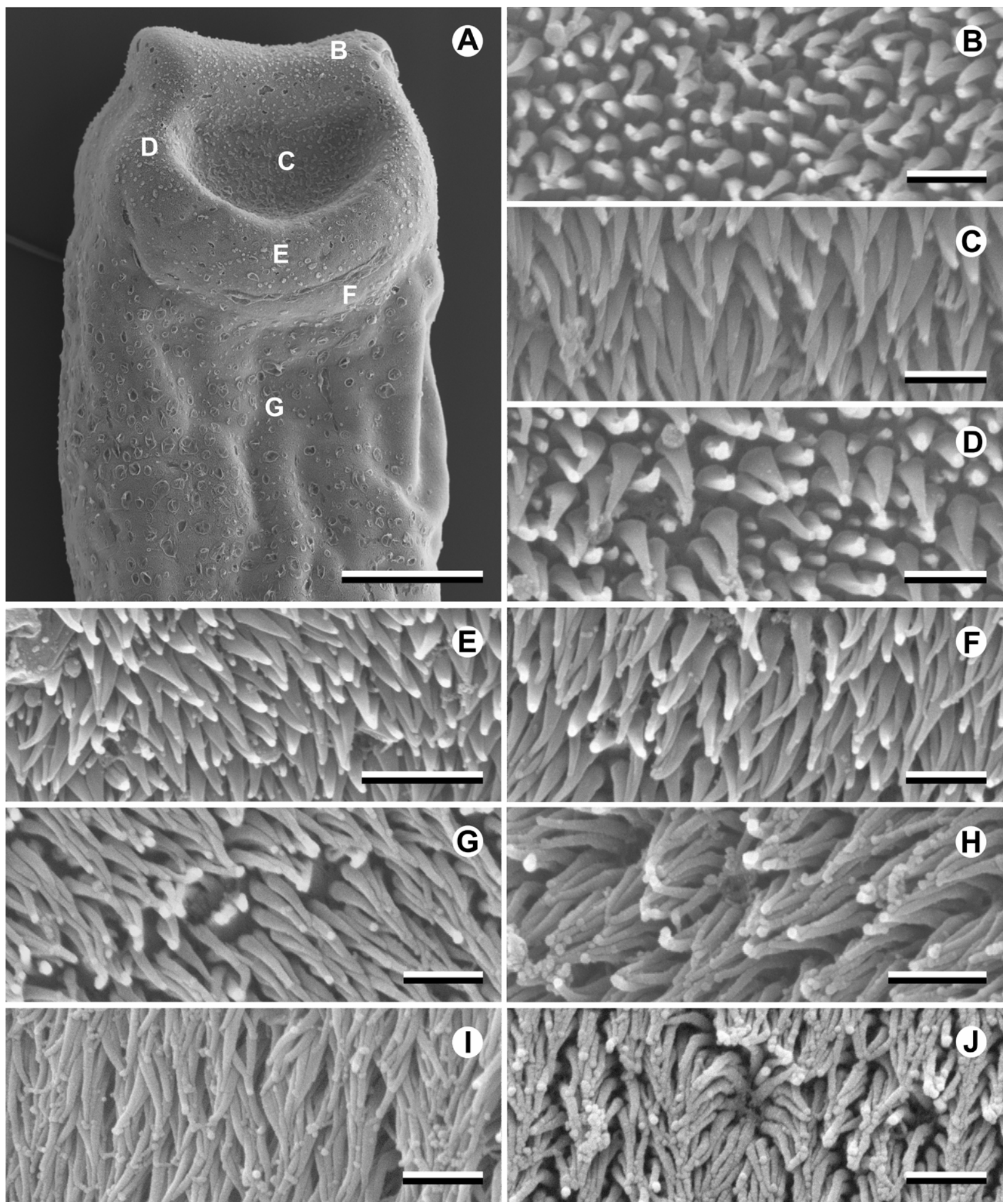

Fig. 15. Scanning electron micrographs of Ailinella mirabilis gen. n., sp. n. A - dorsoventral view of scolex and neck; letters B-G indicate surfaces shown at high magnification in B-G; B - apical disc; C - cavity of bothria; D - lateral marginal ring of bothria; $\mathbf{E}$ - distal marginal ring of bothria; $\mathbf{F}$ - non-adherent surface of bothria; $\mathbf{G}$ - neck. $\mathbf{H}-\mathbf{J}$ - surfaces of proglottides. $\mathbf{H}$ - immature proglottid; I - mature proglottid; $\mathbf{J}$ - gravid proglottid. Scale bars: A = $100 \mu \mathrm{m} ; \mathrm{B}, \mathrm{F}-\mathrm{J}=1 \mu \mathrm{m} ; \mathrm{C}-\mathrm{E}=2 \mu \mathrm{m}$. 
and Probothriocephalus alaini Scholz et Bray, 2001; the internal longitudinal musculature of proglottides is absent; testes are distributed in one central field; the vagina is predominantly anterior to the cirrus sac, and the eggs are operculate and unembryonated.

Among the genera of the Triaenophoridae, the presence of an internal seminal vesicle has sporadically been reported in some species of Abothrium, Bathybotrium, Eubothrium and Parabothrium (see Nybelin, 1922). Further studies will be conducted in order to determine whether A. mirabilis has an internal seminal vesicle or just an enlargement of the deferent canal.

All the surfaces of scolex proper, neck and immature, mature and gravid proglottides of the new species are covered with blade-like spiniform microtriches. The longest blade-like microtriches are found in the central cavity of bothria, whereas the shortest ones are on the apical disc. The highest density of microtriches is observed on the surface of gravid proglottides, whereas the lowest one on the lateral surface of the marginal ring of bothria.

Tumuli (dome-shaped evaginations) (Boyce 1976) or spherical bodies (Andersen 1979) cover all surfaces of the scolex and the anterior surface of the neck in $A$. mirabilis, but they were not observed on the surfaces of the posterior region of the neck and proglottides. The diameter of tumuli, tumulus density, and inter-tumulus distance on the surface of apical disc are similar to those on the lateral surface of the scolex. Some of the tumuli are pinched off due to content release, as observed in other species (e.g., Eubothrium crassum - see Arme and Threadgold 1976).

At present, SEM revealed the presence of tumuli in adults of the following 15 species of Pseudophyllidea: 4 Bothriocephalidae [Bothriocephalus acheilognathi Yamaguti, 1934 (syn. B. gowkongensis Yeh, 1955), B. claviceps (Goeze, 1782), B. scorpii (Müller, 1776), Clestobothrium crassiceps (Rudolphi, 1819)]; 2 Diphyllobothriidae [Schistocephalus solidus (Müller, 1776), Ligula intestinalis (Linnaeus, 1758)]; and 9 Triaenophoridae [Eubothrium acipenserinum Kholodkovski, 1918, E. crassum (Bloch, 1779), E. rugosum (Batsch, 1786), E. parvum Nybelin, 1922, E. salvelini (Schrank, 1790), Galaxitaenia toloi Gil de Pertierra et Semenas, 2005, Triaenophorus crassus Forel, 1868, T. meridionalis Kuperman, 1968, T. nodulosus (Pallas, 1781)] (Arme and Threadgold 1976, Boyce 1976, Andersen 1979, Tedesco and Coggins 1980, Kuperman and Davydov 1982, Granath et al. 1983, Gil de Pertierra and Semenas 2005).

The comparisons of distribution, size, density and inter-tumulus distances among species are difficult due to incomplete data. Tumuli of triaenophorids like $E u$ bothrium spp. and Triaenophorus spp. are generally distributed on the scolex and neck (Arme and Threadgold 1976, Andersen 1979, Tedesco and Coggins 1980, Kuperman and Davydov 1982), but there are some differences among species. For example, Boyce (1976) also observed a high density of tumuli on the lateral surfaces of strobila in E. salvelini, a character not observed in any other species of Eubothrium. In Triaenophorus crassus, Andersen (1979) failed to find tumuli on the apical disc surface or on the anterior surface of scolex, but reported their presence on the marginal ring of bothria and neck. In Galaxitaenia toloi, Gil de Pertierra and Semenas (2005) observed that tumuli were sparsely distributed on the apical disc surface, but they were absent on the surfaces of scolex, neck and proglottides.

Tumuli from different regions of the scolex of $B$. acheilognathi (Bothriocephalidae) (Granath et al. 1983) are smaller (diameter 1.35 on the scolex surface and 0.6-0.7 on the cavity surface of bothria) and intertumulus distances similar (2.4-4.5) than those recorded for A. mirabilis (Triaenophoridae) in the present paper.

There is very little information available on the characterisation and distribution pattern of microtriches in specific regions of scolex, neck and proglottides in pseudophyllidean cestodes. Observations made on the scolex of B. acheilognathi (Granath et al. 1983) show that it is covered with filiform microtriches, and mature and gravid proglottides with small spiniform microtriches.

So far, the tegumental surface of pseudophyllidean cestodes has been fully described only for $A$. mirabilis in the present work and previously, for G. toloi (see Gil de Pertierra and Semenas, 2005). The latter species shows two types of microtriches; the apical disc surface and the central cavity surface of bothria are covered with blade-like spiniform microtriches interspersed with filiform microtriches, and the other surfaces examined are only covered with spiniform microtriches. Ailinella mirabilis has exclusively spiniform microtriches on all the surfaces studied, including those on the gravid proglottides, which were not included in the study of $G$. toloi's tegument.

New morphological features are needed to discriminate among genera and/or species, and morphological studies of the surface of the tegument including type and distribution of microtriches can contribute to this purpose. Recent ultrastructural investigations into the tegumental surface, especially of the scolex, using SEM have provided valuable information suitable for the differentiation of genera and/or species in the Diphyllidea, Lecanicephalidea, Tetraphyllidea and Trypanorhyncha (e.g., Richmond and Caira 1991, Palm 2000, Jensen 2001, Tyler 2001, Caira and Tracy 2002, Ivanov and Campbell 2002, Ivanov 2004).

In comparing Ailinella with the genera of the Triaenophoridae, Amphigonophorus Mendes, 1944 was considered as a valid genus. Kennedy and Andersen (1982), synonymized Amphigonophorus Mendes, 1944 with Anchistrocephalus Monticelli, 1890, but they did not study the type specimens of Amphigonophorus car- 
valhoi Mendes, 1944. Furthermore, Mendes (1944), in her description of $A$. carvalhoi, stated that the uterine pores are dorsal (pp. 182, 187; fig. 14). Recently, Amphigonophorus and Anchistrocephalus were considered as valid by Bray et al. (1994). This fact emphasises the necessity to restudy Mendes' type specimens to clarify the correct taxonomic status of $A$. carvalhoi.

In Argentina, Galaxias maculatus is also parasitized by the following intestinal helminths: Steganoderma szidati Viozzi, Flores et Ostrowski de Núñez, 2000 (Digenea), Allocreadium pichi Flores, Brugni et Ostrowski de Núñez, 2004 (Digenea), Acanthocephalus tumescens (von Linstow, 1896) (Semenas and Trejo 1997) (Acanthocephala), Pomphorhynchus patagonicus Ortubay, Úbeda, Semenas et Kennedy, 1991 (Semenas, unpubl. data) (Acanthocephala), and Camallanus corderoi Torres, Teuber et Miranda, 1990 (Revenga and Scheinert 1999) (Nematoda). Ailinella mirabilis is the sixth intestinal helminth parasitizing G. maculatus. The other Galaxias species in the Argentinean Andean-Patagonian region, G. platei, shares the same intestinal helminths as G. maculatus (Ortubay et al. 1994), except for the absence of $A$. pichi and the presence of the triaenophorid G. toloi (Flores et al. 2004, Gil de Pertierra and Semenas 2005). In Chile, A. tumescens and C. corderoi were the only intestinal helminths recorded in $G$. maculatus (Torres et al. 1990, 1992). It is noteworthy that despite the wide distribution of G. maculatus in the Southern Hemisphere, only two cestode species have been described from this fish, namely the triaenophorid $A$. mirabilis from Andean Patagonian lakes in Argentina, and the nippotaeniid Nippotaenia contorta Hine, 1977 from New Zealand. Ortubay et al. (1994), Rauque et al. (2003) and Revenga et al. (2005) assigned cestodes from G. platei and G. maculatus to the genus Nippotaenia, but such identifications were erroneous because the specimens corresponded to the triaenophorids G. toloi, described in a previous paper (Gil de Pertierra and Semenas 2005) for G. platei, and A. mirabilis described in the present paper for G. maculatus.

Ailinella mirabilis is the second triaenophorid cestode parasitizing galaxiid fishes in Patagonia. Further studies involving other autochthonous fish species in different localities will be undertaken to expand the knowledge of the diversity of cestodes and their hosts in this region.

Acknowledgements. The authors thank G. Pertierra for the graphic design of the plates, and to the reviewers for constructive criticism. Financial support was provided by Universidad de Buenos Aires, Grant UBACyT-X004, Universidad Nacional del Comahue, Grant UNC-B115, and PIP CONICET $\mathrm{N}^{\circ} 2752$, and PIP CONICET N ${ }^{\circ} 5974$ Argentina.

\section{REFERENCES}

ANDERSEN K.I. 1979: Studies on the scolex morphology of Eubothrium spp. with emphasis on characters usable in species discrimination and with brief references on the scolices of Bothriocephalus sp. and Triaenophorus spp. (Cestoda; Pseudophyllidea). Z. Parasitenkd. 60: 147-156.

ANDERSEN K.I., KENNEDY C.R. 1983: Systematics of the genus Eubothrium Nybelin (Cestoda, Pseudophyllidea), with partial re-description of the species. Zool. Scripta 12: 95-105.

ARME C., THREADGOLD L.T. 1976: A unique tegumentary cell type and unicellular glands associated with the scolex of Eubothrium crassum (Cestoda: Pseudophyllidea). Rice Univ. Stud. 62: 21-34.

BERRA T.M. 2003: Family Galaxiidae. In: R.E. Reis, S.O. Kullander and C.J. Ferraris (Eds.), Check List of Freshwater Fishes of South and Central America. EDIPUCRS, Porto Alegre, Brasil, pp. 503-506.

BOYCE N.P. 1976: A new organ in cestode surface ultrastructure. Can. J. Zool. 54: 610-613.

BRAY R.A., JONES A., ANDERSEN K.I. 1994: Order Pseudophyllidea. In: L.F. Khalil, A. Jones and R.A. Bray (Eds.), Keys to the Cestode Parasites of Vertebrates. CAB International, Wallingford, Oxon, pp. 205-247.

CAIRA J.N., TRACY R. 2002: Two new species of Yorkeria (Tetraphyllidea: Onchobothriidae) from Chiloscyllium punctatum (Elasmobranchii: Hemiscylliidae) in Thailand. J. Parasitol. 88: 1172-1180.

CUSSAC V., ORTUBAY S., IGLESIAS G., MILANO D., LATTUCA M., BARRIGA P., BATTINI M., GROSS M.
2004: The distribution of South American galaxiid fishes: the role of biological traits and post glacial history. J. Biogeogr. 31: 103-121.

FLORES V., BRUGNI N., OSTROWSKI DE NÚÑEZ M. 2004: Allocreadium pichi n. sp. (Trematoda: Allocreadiidae) in Galaxias maculatus (Osteichthyes: Galaxiidae) from lake Moreno in Patagonia (Argentina). Syst. Parasitol. 58: 217-221.

GIL DE PERTIERRA A.A. 2002: Nomimoscolex semenasae $\mathrm{n}$. sp. (Proteocephalidea: Monticelliidae), a cestode parasite of Diplomystes viedmensis (Pisces: Siluriformes) from the Patagonian region of Argentina. Syst. Parasitol. 53: 183190.

GIL DE PERTIERRA A.A., SEMENAS L.G. 2005: Galaxitaenia toloi n. gen., n. sp. (Eucestoda: Pseudophyllidea) from Galaxias platei (Pisces: Osmeriformes, Galaxiidae), in the Patagonian region of Argentina. J. Parasitol. 91: 900-908.

GIL DE PERTIERRA A.A., VIOZZI P. 1999: Redescription of Cangatiella macdonaghi (Szidat y Nani, 1951) comb. nov. (Cestoda: Proteocephalidae) a parasite of the atheriniform fish Odontesthes hatcheri (Eigenmann, 1909) from the Patagonian region of Argentina. Neotrópica 45: 13-20.

GRANATH W.O., LEWIS J.C., ESCH G.W. 1983: An ultrastructural examination of the scolex and tegument of Bothriocephalus acheilognathi (Cestoda: Pseudophyllidea). Trans. Am. Microsc. Soc. 102: 240-250.

HANZELOVÁ V., SCHOLZ T., GERDEAUX D., KUCHTA R. 2002: A comparative study of Eubothrium salvelini and 
E. crassum (Cestoda: Pseudophyllidea) parasites of arctic charr and brown trout in alpine lakes. Environ. Biol. Fish 64: $245-256$.

HOBERG E.P., SIMS D.E., ODENSE P.H. 1995: Comparative morphology of the scolices and microtriches among five species of Tetrabothrius (Eucestoda: Tetrabothriidae). J. Parasitol. 81: 475-481.

IVANOV V.A. 2004: A new species of Rhinebothroides Mayes, Brooks \& Thorson, 1981 (Cestoda: Tetraphyllidea) from the ocellate river stingray in Argentina, with amended descriptions of two other species of the genus. Syst. Parasitol. 58: 159-174.

IVANOV V.A., CAMPBELL R.A. 2002: Notomegarhynchus navonae $\mathrm{n}$. gen. and $\mathrm{n}$. sp. (Eucestoda: Tetraphyllidea), from skates (Rajidae: Arhynchobatinae) in the Southern Hemisphere. J. Parasitol. 88: 340-349.

JENSEN K. 2001: Four new genera and five new species of lecanicephalideans (Cestoda: Lecanicephalidea) from elasmobranchs in the Gulf of California, Mexico. J. Parasitol. 87: 845-861.

KENNEDY C.R., ANDERSEN K.I. 1982: Redescription of Anchistrocephalus microcephalus (Rudolphi) (Cestoda, Pseudophyllidea) from the sunfish Mola mola. Zool. Scripta 11: 101-105.

KUCHTA R., SCHOLZ T. 2004: Bathycestus brayi n. gen. and n. sp. (Cestoda: Pseudophyllidea) from the deep-sea fish Notacanthus bonaparte in the Northeastern Atlantic. J. Parasitol. 90: 316-321.

KUCHTA R., SCHOLZ T. 2006: Australicola pectinatus n. gen. and n. sp. (Cestoda: Pseudophyllidea) from the deepsea fish Beryx splendens from Tasmania. J. Parasitol. 92: 126-129.

KUPERMAN B.I., DAVYDOV V.G. 1982: The fine structure of frontal glands in adult cestodes. Int. J. Parasitol. 12: 285-293.

MENDES M.V. 1944: Sôbre Cestoda de teleósteos marinhos. Bol. Fac. Fil. Ciên. Let. Univ. São Paulo 43: 173-187.

NYBELIN O.N. 1922: Anatomisch-systematische Studien über Pseudophyllideen. Göteborgs Kungliga Vetenskapsoch Vitterhets Samhälles Handlingar 26: 1-228.

ORTUBAY S., SEMENAS L., UBEDA C., QUAGGIOTTO E., VIOZZI G. 1994: Catálogo de Peces Dulceacuícolas de la Patagonia Argentina y sus Parásitos Metazoos. Dirección de Pesca, Subsecretaría de Recursos Naturales, Río Negro, Argentina, $110 \mathrm{pp}$

PALM H.W. 2000: Trypanorhynch cestodes from Indonesian coastal waters (East Indian Ocean). Folia Parasitol. 47: $123-134$.

RAUQUE C.A., VIOZZI G.P., SEMENAS L.G. 2003: Component population study of Acanthocephalus tumescens
(Acanthocephala) in fishes from Lake Moreno, Argentina. Folia Parasitol. 50: 72-78.

REVENGA J., SCHEINERT P. 1999: Infections by helminth parasites in "Puyenes", Galaxias maculatus (Galaxiidae, Salmoniformes), from Southern Argentina with special reference to Tylodelphys barilochensis (Digenea, Platyhelminthes). Mem. Inst. Oswaldo Cruz 94: 605-609.

REVENGA J., TORRES P., BAIZ M. 2005: Impact of a caged-trout farm on parasites of Galaxias maculatus in Lake Moreno, Southern Argentina. J. Parasitol. 91: 707709.

RICHMOND C., CAIRA J.N. 1991: Morphological investigations in Floriceps minacanthus (Trypanorhyncha: Lacistorhynchidae) with analysis of the systematic utility of scolex microtriches. Syst. Parasitol. 19: 25-32.

SEMENAS L., TREJO A. 1997: Redescription of Acanthocephalus tumescens (von Linstow, 1896) (Palaeacanthocephala: Echinorhynchidae) in Galaxias maculatus (Pisces: Galaxiidae) in Patagonia (Argentina). Syst. Parasitol. 36: $13-16$.

SURIANO D.M., LABRIOLA J.B. 1998: Redescription of Anonchocephalus chilensis (Riggenbach, 1896) (Pseudophyllidea: Triaenophoridae) and description of $A$. patagonicus n. sp. Bol. Chil. Parasitol. 53: 73-77.

TEDESCO J.L., COGGINS J.R. 1980: Electron microscopy of the tumulus and origin of associated structures within the tegument of Eubothrium salvelini Schrank, 1790 (Cestoidea: Pseudophyllidea). Int. J. Parasitol. 10: 275-280.

THOMPSON R.C.A., HAYTON A.R., JUE SUE L.P. 1980: An ultrastructural study of the microtriches of adult Proteocephalus tidswelli (Cestoda: Proteocephalidea). Z. Parasitenkd. 64: 95-111.

TORRES P., CONTRERAS A., CUBILLOS V., GECHE W., MONTEFUSCO A., REBOLLEDO C., MIRA A., ARENAS T., MIRANDA J., ASENJO S., SCHLATTER R. 1992: Parasitismo en peces, aves piscívoras y comunidades humanas ribereñas de los lagos Yelcho y Tagua Tagua, X Región de Chile. Arch. Med. Vet. 24: 77-91.

TORRES P., FRANJOLA R., CABEZAS X., COVARRUBIAS C. 1990: Distribución de la infección por Camallanus corderoi (Nemata: Spiruroidea) en distintos hospedadores autóctonos y sectores de la cuenca del río Valdivia, Chile. Bol. Chil. Parasitol. 45: 55-59.

TYLER G.A. 2001: Diphyllidean cestodes of the Gulf of California, México with descriptions of two new species of Echinobothrium (Cestoda: Diphyllidea). J. Parasitol. 87: 173-184.

YAMAGUTI S. 1959: Systema Helminthum. Vol. II. The Cestodes of Vertebrates. Intersciences Publishers, New York and London, $860 \mathrm{pp}$. 